\title{
The Rule of Freedom
}

\author{
DOI: $10.35757 /$ CIV.2009.11.13
}

Can liberty govern a state? Can authority be a power at the service of liberty? A thesis thus formulated must raise certain doubts, since according to popular opinion any rule, and in particular a political rule which is granted certain instruments of power, may seem to actually be the greatest threat to human liberty. Or is the only way to convey the mutual relationship between these two phenomena through a violent opposition: power versus liberty?

Authority has often been, and continues to be perceived as authority through despotism, of violence and force. When we consider various examples from the history of governments, we can see that one particularly stands out: the right to rule in the name of liberty. Reference here is made, of course, to the project of the modern state, in which the legality of all institutions is measured by human liberty and the extent to which it is satisfied. Hegel, in fact, has already once written on this kind of state, saying that it constitutes "das Reich der verwirklichten Freiheit" - the kingdom of realized liberty.

But what does the phrase "to rule in the name of liberty" actually mean? How can liberty be implemented through state institutions? And finally, what kind of liberty are we talking about here, since this concept is generally acknowledged as ambiguous? This issue demands a much more thorough analysis.

Zbigniew Stawrowski - philosopher of politics, professor at the Institute of Political Studies of the Polish Academy of Sciences in Warsaw (Philosophy of Politics Department) and chair of History of Ideas and Political Doctrines Department in the Institute of Politology at Cardinal Stefan Wyszyński University in Warsaw. Director of the Józef Tischner Institute in Cracow. 
It is a well-known fact that the problem of liberty first emerged as the central problem of politics in the modern period. However, the meaning of liberty becomes more intelligible for us if we refer it to issues not only raised much earlier, but also to much more fundamental ones. The problem of liberty in its social and political context to which we are actually referring here is only a contemporary modification of the principal question of political philosophy, the question of justice, of a just state, a question formulated much earlier, in the Age of Antiquity.

According to the classical definition of the word, justice consists in giving to each that which he rightfully deserves; it follows, therefore, that the task of the State's authority is to serve justice thus understood. The basis of measuring what one rightfully deserves was, during the Age of Antiquity and of the Middle Ages, the order of natural laws, that is, laws in accordance with the rational nature of man and evident to anyone who employs reason. The ultimate character of those all-obliging laws was established by Divine Authority. The cosmic order, understood as the work of the Creator, entailed the hierarchical order of created beings of varying degrees of perfection governed by laws of nature, at the summit of which was man. For as a rational being, man governed himself, and in following the dictates of his reason, he likewise gave testimony to the measure of justice, received from a universal order, that is ultimately from his Divine Creator.

The certainty of the existence of an order of natural laws did not, of course, mean that the significance of some of its laws was not a matter of controversy. The most striking example is the approach to democracy at the time. Along with the dominant attitude affirming that hierarchy was the natural law that bound all, including the world of human relationships, which meant rejecting the egalitarianism of democratic ideas as contrary to reason, other opinions emerged acknowledging democracy as a political system no less legitimate than aristocracy or monarchy, which depending on the conduct of those in power, as in other forms of 
government, could be just or not. Regardless of one's judgements, one assumption was definitely common to all: only the just rule could be legitimate. A just authority, therefore, is ultimately one who serves as the guardian and servant of the rational and natural order, ensuring that this order is observed in public life.

In modern times, the conviction that a natural order of created beings existed and that man was one of its elements began to wane and lose importance. Another opposing vision emerged, a vision where man was understood as the only creator of interpersonal order and ultimately, therefore, the only one who could be a measure of its structure. The idea of liberty, which from then on would gain international popularity, reflects this new, homocentric point of view. With respect to the discipline of politics, this meant that the general principle of "the rule at the service of justice" meant "rule in the service of liberty." Here liberty has become the true ruler of the modern State.

This does not mean of course that the category of justice ceased to oblige. Rather, this signifies a change in the ultimate point of view for measuring what is just. To acknowledge that man is in essence free, means that he has been granted an absolute and central status, the status of one who rightfully deserves everything. In consequence, man and his liberty have now become the measure of justice for the social and political order. All institutions established by man therefore now stand before the tribunal of human liberty. Those which do not serve liberty, or which even violate it, by this perspective have now become unjust and illegitimate.

In order to understand the modern state as a rule of liberty, one must investigate the essence of liberty itself. It is widely known that liberty can be viewed in many ways. Isaiah Berlin, for instance, speaks of over two hundred meanings of liberty mentioned by historians of ideas. ${ }^{1}$ Not all of them, of course, are of 
equal significance to the issue under present consideration: What kind of liberty can govern the contemporary political order? Among the philosophers who have examined authority from the point of view of liberty is Benjamin Constant, who has distinguished liberty understood as personal security from liberty recognized as participation in political life, and who has likewise stressed that these two understandings of liberty are complementary. ${ }^{2}$ Another widely known vision of freedom is the division of liberty into negative and positive; the latter, in Berlin's original understanding of the term, remains unclear. Such doubts however do not apply to the negative concept of liberty, as Berlin called it, or its equivalent in Constant's understanding of liberty understood as personal security. Both authors concur that this understanding of liberty is fundamental, and should above all find its expression in contemporary state institutions. In order to reveal the logic of liberty thus understood, we must turn to its very roots; that is, to Thomas Hobbes's concept of liberty. For it is Hobbes who first precisely defined that understanding of liberty, and who first consciously engaged in designing a state based from start to finish on the liberty of the individual.

What we today term "negative liberty" can be traced back to Hobbes, who defines liberty as the lack of external impediments of motion. As we read in Leviathan: "Liberty is understood, according to the proper signification of the word, the absence of external impediments"; ${ }^{3}$ in yet another part he says that "Liberty, or freedom, signifieth (properly) the absence of opposition; (by opposition, I mean external impediments of motion)." ${ }^{4}$ Let us pause and examine these statements more closely. According to these statements, liberty is first and foremost understood as something external; it is, so to speak, a kind of external space, in which the individual subject moves about. This space of liberty,

\footnotetext{
${ }^{2}$ Cf. Benjamin Constant: The Liberty of the Ancients Compared to That of the Moderns, in: idem: Political Writings, Cambridge University Press, Cambridge 2003, pp. 308-328.

3 Cf. Thomas Hobbes: The Leviathan, Oxford University Press, Oxford 1998, p. 86.

4 Ibidem, p. 139.
} 
like any other kind of space, is something which is possessed, to a lesser or greater extent. Secondly, liberty is thus defined not by attributes inherent to the individual subject who possesses liberty, but rather by something external to it. It is precisely in this respect that we can speak of a negative definition of liberty, in that it defines liberty not by what it is in itself, but according to the negation of something it is not (which is the exact meaning of the formulation: absence of external impediments). When we speak therefore of negative liberty, in principle we do not define liberty in itself, but only certain necessary and external conditions which make liberty possible.

Hobbes's starting point is what he terms a natural condition of man, a state of nature; an extreme condition where the freedom of a man is completely unlimited. An individual who is not opposed by anything perceives himself, his Self, as the absolute center of such a space. His natural right, therefore, is to enjoy this liberty, understood as the right to do anything in accord with his will. Such an individual does not perceive other men as limitations or boundaries, but only as objects which can be of potential use, just as the same individual is equally perceived by other men as a similar object. But this gives rise to an essential doubt: there may be many egocentric individuals, but the common center of space for all these individuals can only be one.

There are only two possible solutions to such a dilemma: an endless life-and-death struggle with everyone to gain absolute control of this common space. The other solution entails that these egocentric individuals acknowledge the value of personal security, and thus avoid conflict with others as a matter of utmost importance. The latter solution, in turn, is based on restricting an individual's liberty and the mutual withdrawal from the natural right to everything; in other words, it entails the division of this common space into smaller, limited spaces, in which each individual may continue to remain the absolute center. Individuals continue to remain free, but only within a small parcel of space. 
The most basic institution of such a state in society is what has become the inviolable private sphere, which is the necessary condition for both respecting a sense of personal security, and maintaining the limited space where each individual can move about freely. This is the absolute right to property understood in a very broad sense. These rights to life, liberty and property, create the first and fundamental dimension of the contemporary state. This dimension, based on the concept of negative liberty, demarcates the inviolable external boundary within which men can freely move, in which they can safely enact what they understand as their liberty.

Thomas Hobbes's basic concept of freedom also justifies a principle which forms the basis of every contemporary state: "that a man be willing, when others so too, as far-forth, as for peace, and defence of himself he shall think it necessary, to lay down this right to all things; and be contented with so much liberty against other men, as he would allow other men against himself." ${ }^{5}$ The acceptance of the postulate of complementarity and commensuracy of self-limitation directly leads to what today we call equality before the law, and to the philosophical foundation of the judicial branch as an impartial judge, whose basic duty is to ensure the right to impartiality in situations of conflict; that neither of the sides shall be treated better or worse. To put his principle into simple and concrete terms, Hobbes enumerated an entire catalogue of reasonable laws, which must all be observed so that every individual may feel safe in a State, and which may be reduced to the rule "Do not that to another which thou thinkest unreasonable to be done by another to thyself."

In analyzing Hobbes' thought, one cannot ignore the most striking paradox of the model the philosopher proposes. That is, it would lead to the reduction of political rule into an artificial adjunct. In illustrating the structure of a peaceful state of coexistence with

Ibidem, p. 87.

6 Ibidem, p. 180. 
its basic pillars, the guarantee of personal security and equality under the law, Hobbes is aware that a theoretical legitimacy of such a structure cannot suffice for liberty to exist and function properly. For there will always be someone who tries to violate these basic rights, "the laws are of no power to protect them, without a sword in the hands of a man, or men, to cause those laws to be put in execution." Authority is therefore needed, that sword of justice, with whose force the equality of rights and the personal security of individuals shall be insured. Who therefore must be that authority or sovereign, since this role would imply the guardian of justice? What can encourage him to fulfill his role diligently? It is certain that it can not be a person who, as Hobbes described, is egocentric, who is forced to observe the laws of conviviality out of a sense of his inferiority or out of fear for his life. For in this case, should he be granted enough power, he would only employ it against others. The concept of man and of liberty, in Hobbes's understanding, therefore leads to an irresolvable contradiction. The introduction of an institution of authority, that is the introduction of an individual subject who disposes of physical means of force and coercion in order to guarantee peace and to secure the liberty of individuals, has become not only a necessary prerequisite for the functioning of the Hobbesian model, but also is something which continually destabilizes the internal order of the structure of which it is a prerequisite.

It would be worth recalling two ways of solving such a dilemma. First of all, the better known solution was proposed by the fathers of liberalism; it was an attempt at depersonifying the sovereign, and thus weakening his position, transforming the ruler into an impersonal institution of increasing restrictions and vague responsibilities. The second solution is one proposed by Hegel, the dialectics of the master and servant as a reply to the state of nature dilemma in Hobbes. According to the author of the

\footnotetext{
7 Ibidem, p. 141.
} 
Phenomenology of Spirit, the first social relationship is not, as Hobbes had thought, a horizontal relationship of two subjects equal to each other; it is rather a vertical relationship of the bondsman to his lord. The irresolvable problem, therefore, of the origin of the non-egocentric and therefore inhuman, just sovereign is nonexistent here. What exists is the problem of liberating the individual, and of the gradual broadening of the scope of his freedom within the limits of the primeval and ever present existing power structure.

Another essential weakness of the Hobbesian model is the lack of a public sphere. In principle we are dealing with monads, closed and restricted within their own private spheres, for whom mutual relationships are reduced to exchange, by way of contracts, of objects belonging to them. On the other hand, this also reduces the ruler of the state into a person whose task is to supervise the relationships between individuals so that they do not enter into conflict.

It may be worth considering, if in limiting the absolute liberty related to the emergence of the social condition of the State, one should only see the restriction of freedom. For the boundaries that each individual willingly imposes on himself are self-imposed limitations internal to himself and not, therefore, external hindrances. This brings us to yet another question: Is freely limiting one's own liberty a limitation of freedom, or is it, on the contrary, the realization of freedom? We are however speaking of a completely different kind of liberty here, one that is distinct from the negative concept of liberty; a kind of liberty which we can find in Hobbes himself, 8 particularly where the philosopher concludes that one can speak of freedom as the

\footnotetext{
8 Cf. the term "liberty of man" contained in the first and fundamental formulation of the natural law: "The Right of Nature, which writers commonly call ius natural, is the liberty each man hath, to use his own power, as he will himself, for the preservation of his own nature; that is to say, of his own life; and consequently, of doing any thing, which in his own judgment, and reason, he shall conceive to be the aptest means thereunto." T. Hobbes: op. cit., p. 86.
} 
absence of opposition, "and may be applied no less to irrational, and inanimate creatures, than to rational." Freedom of movement applies here to the movement of a river current, or the swinging of a pendulum. There is, however, a significant difference between an object previously set in motion and a man who moves himself. The latter concept of liberty, as implied by Hobbes, is one in which man is seen as the source of movement in itself, or the source of action. What the philosophers of antiquity called the soul, ${ }^{10}$ and what Kant used most emphatically in the modern era in his concept of autonomous will, defined as such: "will is the faculty of determining oneself into action in accordance with the conception of certain laws." 11 In this respect, man's liberty becomes evident chiefly in his autonomy - a faculty which makes him the primal origin of all forms of activity he initiates.

To consider this perspective, in which liberty means the capacity for independent action, would imply that for Hobbes's model of the modern State of liberty, itself based on the negative concept of liberty and thus postulating the respect of personal security and the principle of legal equality of all individuals, needed to be supplemented with still other institutions. Let us here recall one of the classical fathers of nineteenth-century liberalism, John Stuart Mill, for whom liberty was first and foremost the freedom to act. In his understanding of freedom, Mill differentiates three dimensions of liberty. The first would be the inward domain of our consciousness, in which absolute liberty of our conscience rules, and consequently the right to absolute freedom of thought and expression of opinion in all things. The second sphere deals with the external freedom of framing the plan of our life to suit our own character, under the condition that we are prepared to bear the consequences of our actions and they do not harm anyone. The third sphere is an extension of the second, and covers external

\footnotetext{
${ }_{9}$ Ibidem, p. 85.

${ }^{10}$ Cf. Plato: Phaedrus, Book XXIV.

${ }^{11}$ Immanuel Kant: Grundlegung zur Metaphysik der Sitten [Fundamental Principals of the Metaphysics of Morals] (IV 427).
} 
actions which are done in cooperation with other men, which in turn signify the freedom to unite, for any coomon purpose, while avoiding doing others harm. ${ }^{12}$

In the Hobbesian model of the State, absolute liberty of action is allowed, but only within the private sphere, where everyone is free to do with his possessions as he wants. However, the three dimensions of liberty explained by Mill allow for the formulation of conditions which a State must fulfill if the liberty of actions of autonomous individuals in the public sphere be realized. In such a State, certain institutions must exist to guarantee every man liberty of thought, word and action. Certain activities and associations should be restricted only if they might cause harm to others. Summarizing then, Mill writes: "No society in which these liberties are not, on the whole respected, is free, whatever may be its form of government; and none is completely free in which they do not exist absolute and unqualified. The only freedom which deserves the name, is that of pursuing our own good in our own way, so long as do not attempt to deprive others of theirs, or impede I their efforts to obtain it." 13

A State whose primary axiom is absolute respect for the freedom of an individual's action, and whose only restriction is that these actions neither harm others nor interfere with their personal dimension of freedom is a liberal State in the most classical sense - a State whose fundamental axiom is precisely laissez faire to allow to act, or rather not to interfere with action. The role of authority is therefore limited to that of a "watchman," who ensure that safety, order and the regulations of justice are respected. The minimal obligation of authority is equivalent to the maximal extent of individual liberty. Those in power seek to implement one aim: to ensure that the liberty of citizens may be further developed and broadened. One can likewise affirm that there is

\footnotetext{
${ }^{12}$ Cf. John Stuart Mill: On Liberty and Other Essays, Oxford University Press, Oxford 1998, pp. $16-17$.

${ }_{13}$ Ibidem, p. 17.
} 
no other theoretical model of the State which could implement liberty thus understood in a way as radical and coherent as the laissez faire State.

This does not mean that this State model should be uncritically acknowledged as the perfect organization of social life. Its weaknesses are evident, and indirectly related to its main axiom. It is certain that a liberal state precisely and effectively frames the coexistence of autonomous individuals for whom absolute freedom activity is the most important virtue. But it completely ignores those whom for one reason or another do not fit into this idealized model (i.e. children, the sick, disabled, and many others who suffer serious problems). Should those in power allow those people to work and live independently, turning a blind eye to their capacities? Or should the State in this case provide them with some help and assistance? A classical liberal would probably answer that under no circumstances do these questions affect the minimal model of the State, as help and assistance for those in need should arise as a charitable initiative undertaken by private individuals out of their own free will. Such an answer however would go beyond the individualistic concept of liberty understood as the capacity of individuals to undertake individual initiatives. For it is based on the assumption that helping others is in fact something unconditionally essential, that supporting others is a clear duty for us all. In other words, we are all tied to each other by an ethical bond. In this respect, liberty as autonomy is made complete by fulfilling certain obligations with respect to others. It turns out that this is the liberty of the individual, who in his independent activities discovers the social dimension of his own self, and his real roots and foundation in a concrete community.

These kinds of doubts have always been present in the criticism of the minimum state model and the concept of man and liberty at its foundation, adopted from various systems of thought, such as socialist, Christian or even conservative. This in turn led 
to the gradual shift from the idea of the State as the "watchman" to a State of a much wider field of intervention. Today, however, all states that are welfare states to a greater or lesser degree would still refer to the idea of liberty as their legal foundation; this is only appropriate insofar as this idea is understood differently and is the ultimate source of legitimacy for additional institutions which were later introduced and differ from the laissez faire State.

Generally speaking, we are dealing here with various kinds of institutions connected with the democratic political system. Its legitimacy is based on the conviction that the universal and equal right to participate in the authority of the State is but a consequence of the assumption that man is an autonomous subject. However, it should be noted that acknowledging autonomy as an axiom may have a dual meaning, and may lead to a dual argument in favor of the democratization of authority.

The first argument which supports the democratic system argues that, since every man is essentially autonomous, he deserves the right to unconditional liberty and freedom within his private sphere; yet since he also possesses the indispensable right to participate in all forms of initiatives in the public sphere that do not harm anyone, it is therefore clear that he must also hold the right to participate in the political sphere, and should be given the opportunity to form and join associations to exercise power within the State. Political activity is here understood like any other kind of activity, which in turn suggests that political institutions in a democratic system draw their legitimacy from the same source as institutions of the minimal state, that is, from the liberal concept of the liberty to act. The evolution of the laissez faire liberal state into a liberal-democratic state thus becomes something completely natural. Such a democratized project of the minimal state can still be acknowledged as a project for a state of liberty, while the fact that such a state is governed in a democratic manner would not infringe on its liberal essence. We can see that within this line of argumentation one can easily 
justify every man's right to participate in politics; however, it does not demonstrate that such a democratically exercised kind of rule may in a legitimate way perform other initiatives much broader than that of simply being a "watchman."

Furthermore, the freedom to join and form political associations is from the liberal perspective mentioned earlier, only one of the many possibilities. Should we decide not to take advantage of it, we do not deprive ourselves of the right to initiative, which we can realize in other fields. The political system of a liberal state is therefore completely irrelevant to the autonomous individual.

With reference to the democratic system, this means that while it is not contradictory to the principle of autonomy i.e. of the freedom to act and can be easily justified by this principle it is on the other hand impossible to prove, as if democracy was its necessary and obvious consequence.

The liberal way of arguing allows for the existence of democratic institutions; yet it does not explain the predominant contemporary "idolatrous" approach to democracy, in which that system is shown not only as one of many possibilities available to free men, but as the unquestionable ideal and aim. This conviction undoubtedly arises from another source, and in fact derives from another understanding of liberty. From the perspective of the liberal concept of freedom, the question of rule is of secondary relevance; State rule should be only an instrument that remains in the service of freely acting individuals. However, from the democratic perspective, where participation in power is presented as an inevitability, and thus is seen as the highest form of realization of human autonomy, power in itself turns into something primary, the essence of human liberty.

The second "democratic" argument which justifies not only the possibility, but rather the necessity of introducing the institution of the democratic system also draws from the idea of autonomy. However, it extracts only those elements related to power and authority. Liberty and freedom as autonomy, as the capacity for 
self-determination, may be likewise understood as the most primal form of power: the power over oneself, over one's possessions, and over one's works, and over others and what belongs to them as well. In this sense, I am more of a man, the more I am able to expand my sphere of rule and governance. Should there be any area over which I have no influence, and which thus constitutes a restriction of my power, then my freedom and humanity are not fully realized. As an autonomous being, I control my own life and therefore have the right to decide according to what I deem is correct; I must therefore not only decide over my own private affairs, but also over those of others which concern me in one way or another, and in issues decided upon by those who are in political power. From this point of view, the postulate of participation in political power becomes the highest moral imperative, and only that State which possesses institutions which can guarantee the right to participate in political power deserves the name of a State of Liberty.

In other words, we can say that the "democratic" argumentation in considering the State introduces the category of the aim. Should we accept the principle of liberty to act along with the liberal model, then we should not be concerned with where this freedom thus conceived may lead, nor should we be interested in what that freedom claims to be its end, on the condition that it does no one any harm. The rule in such liberal model should respect the liberty of individuals and maintain their security; in other words, the rule here only serves as a means. On the other hand, in the "democratic" way of thinking, among the many possible opportunities available to individuals choosing how to lead a good life, one particularly stands out: participation in political activity becomes everyone's moral duty. Political activity differs from other forms of activities because its aim is to rule. Therefore, if in a liberal State the aim of the rule is to guarantee the liberty of all, then in a democratic State the aim of the liberty of all is to rule. 
Both models of the State, though closely intertwined with each other in today's world, still differ from each other in essence, and continue to remain in a state of deep, internal conflict. In the same way that the liberal model tolerates any political system on the condition that it does not destroy the fundamental liberty of individuals, so the democratic does not possess any internal restrictions that should prevent those with political authority from interfering with the private sphere of its citizens, and with what concedes their public activity. It is crucial for the future fate of the contemporary State of liberty that these questions arising from the coexistence of these two different modes undergo thorough study and analysis. ${ }^{14}$ It can be concluded, though, that contemporary States are not liberal-democratic, but rather democratic-liberal States. For they are governed by the democratic principle and the liberty, whose essence is not the liberty to act, but the freedom understood as the desire of power after power; while the historical legacy of liberalism, though still present, only but accompanies the democratic principle, having been more and more reduced to something marginalized.

Translated by Clarinda Calma

First edition: Władza wolności, "Civitas. Studia z Filozofii Polityki” 2001, vol. 5, pp. 56-70.

\footnotetext{
${ }^{14}$ Some of these problems I have discussed in other articles: Liberalizm a demokracja [Liberalism and Democracy], in: J. Miklaszewska (ed.): Liberalizm u schytku XX wieku, [Liberalism at the Waning of the XX Century] Kraków 1999, pp. 59-73 and in Democracy as a Confessional State, "Totalitarian Movements and Political Religions" 2001, vol. 2, no. 2, pp. 39-53.
} 